Original Article

\title{
Burnout syndrome in Brazilian and Spanish nursing workers*
}

\author{
Maria Baldonedo-Mosteiro ${ }^{1}$ \\ (1D) https://orcid.org/0000-0001-9729-7119 \\ Mirian Cristina dos Santos Almeida 2,3 \\ (iD) https://orcid.org/0000-0002-9178-1345 \\ Patricia Campos Pavan Baptista ${ }^{4}$ \\ (D) https://orcid.org/0000-0003-1433-6456 \\ Marta Sánchez-Zaballos ${ }^{5}$ \\ (1) https://orcid.org/0000-0001-8379-5395 \\ Francisco Javier Rodriguez-Diaz ${ }^{1}$ \\ (1) https://orcid.org/0000-0002-5899-439X \\ Maria Pilar Mosteiro-Diaz ${ }^{5}$ \\ (D) https://orcid.org/0000-0002-3375-9334
}

\footnotetext{
* Supported by Fundação de Amparo à Pesquisa do Estado de São Paulo (FAPESP), Brazil - Grant \# 2017/17759-0.

1 Universidade de Oviedo, Departamento de Psicologia, Oviedo, Astúrias, Spain.

2 Universidade Federal do Tocantins (UFT), Curso de Enfermagem, Palmas, TO, Brazil.

3 Scholarship holder at the Coordenação de Aperfeiçoamento de Pessoal de Nível Superior (CAPES), Brazil.

${ }^{4}$ Universidade de São Paulo (USP), Escola de Enfermagem, São Paulo, SP, Brazil.

${ }^{5}$ Universidade de Oviedo, Departamento de Medicina, Oviedo, Astúrias, Spain.
}

Objective: to analyze the burnout dimensions scores in Brazilian and Spanish nursing workers. Method: quantitative, cross-sectional and comparative study conducted with 589 Nursing workers who answered the Sociodemographic and Professional Characterization Questionnaire and the Maslach Burnout Inventory. Descriptive and analytical analysis of the data was performed. Results: Spanish Nursing workers presented higher averages in the Depersonalization dimension ( $p=0.004)$ and Brazilians, higher scores in the Professional Achievement dimension ( $p=0.031$ ). In both Spain and Brazil, nursing assistants / technicians were found to have higher Emotional Exhaustion than nurses; In Brazil, Depersonalization is higher in nurses and in Spain it is higher in Nursing assistants / technicians. Statistically significant results were found in the association of burnout dimensions with sociodemographic and work characteristics: age; professional category; workplace; work regime; work shift; time of professional experience; working time in the same workplace and consider stressful work. Conclusion: Although Brazilian and Spanish nursing workers score low levels of Depersonalization and high Professional Achievement, there are average levels of Emotional Exhaustion, indicating an important preventive factor to be worked on, since Emotional Exhaustion is considered the first stage of burnout.

Descriptors: Burnout, Professional; Despersonalization; Nursing; Nursing Staff; Health Personnel Management; Occupational Health.

\section{How to cite this article}

Baldonedo-Mosteiro M, Almeida MCS, Baptista PCP, Sánchez-Zaballos M, Rodriguez-Diaz FJ, Mosteiro-Diaz MP. Burnout syndrome in Brazilian and Spanish nursing workers. Rev. Latino-Am. Enfermagem. 2019;27:e3192.

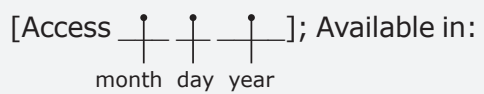
DOI: http://dx.doi.org/10.1590/1518-8345.2818.3192. 


\section{Introduction}

Mental disorders in nursing workers have become more expressive in the last decade, highlighting a serious problem in the field of occupational health and for health services in the international context(1-3).

Among mental disorders, burnout, a psychosocial syndrome that arises in response to chronic work stressors, consisting of Emotional Exhaustion (EE), Depersonalization (DE) and Professional Achievement $(P A)^{(4)}$, has been the subject of many investigations. Recent systematic review found that countries around the world are recognizing the impact of worker burnout and mental strain on productivity, especially the number of days lost and the impact on work ability ${ }^{(1)}$. Other studies indicate psychic disorders and burnout as responsible for most of the restrictions in nursing, intention to leave the profession, poor quality of care, increased errors, reflecting on patient safety ${ }^{(3,5-6)}$.

Despite some peculiarities, the nursing work process happens similarly in different countries due to the inherent characteristics of care and its practical implications related to constant emotional tension, need for concentration, attention and great responsibility ${ }^{(7)}$. In addition, the nature of health work, characterized by the experience of pain, suffering and loss of patients, may affect workers, leading to the emergence of burnout syndrome(2).

However, burnout and other psychic disorders have been the target of investigations from the perspective of working conditions analysis and detailing of the variables that permeate this construct( ${ }^{(8-11)}$. In this sense, organizational issues in Brazilian and European Nursing work have also been reflected in the physical and mental illness of workers due to adverse working conditions aggravated by the recent economic crisis, which exposed the workers of these scenarios to increased work overload, poor dimensioning of human resources, increased informal ties and fear of unemployment ${ }^{(8,10,12)}$.

These results have implications for the field of studies and practices in occupational health, revealing the need for protective measures to the mental health of health team professionals, especially Nursing.

In both Brazil and Spain, the Nursing team is made up of nurses, professionals with higher education, and nursing assistants / technicians, who professionalize with a shorter course, of medium level. The role of nurses involves more complex actions of care and team management, while assistants / technicians are responsible for the development of less complex activities and greater physical demands, such as patient hygiene and bed cleaning. By considering the data presented, the similarity of work contexts and the importance of diagnosing to intervene and prevent injuries to workers and, consequently, organizations and patients, this study aimed to analyze the scores of burnout dimensions in Brazilian and Spanish Nursing workers.

\section{Method}

Quantitative, cross-sectional and comparative study using non-probability convenience sampling consisting of 589 Brazilian and Spanish Nursing workers (nurses, nursing assistants/technicians). The ethical precepts in force in each country followed, and the study was approved in Brazil by the Research Ethics Committee of the University of São Paulo School of Nursing (opinion 912.483 of $11 / 17 / 2014$ ) and in Spain by the Regional Ethics Committee Asturias Clinical Research Code 83/15). This research is part of the multicenter project entitled "From work contexts to occupational health of nursing professionals, a comparative study between Portugal, Brazil and Spain", developed between the University of São Paulo School of Nursing, the University of Oviedo, the University of Porto and the Porto School of Nursing.

Data collection was performed by two of the authors, between June 2015 and December 2016, in four public hospitals and one pre-hospital in the north coast of São Paulo, Brazil, and in six hospitals and six pre-hospital institutions of a province of northern Spain.

In both Brazil and Spain, the following data collection procedures were adopted: previously, the managers of the health institutions were verified the most favorable days and times for the invitation to Nursing workers to participate in the study; these were addressed individually in the workplace and, after clarification of the research content and relevant ethical aspects, the questionnaires, together with the Free and Informed Consent Term (FICT), They were distributed and subsequently collected, at a scheduled date and time, in a sealed envelope, without external identification, seeking to ensure the confidentiality and reliability of the information, as well as not interfering with the work routine. Nursing workers from the institutions that authorized the study application were eligible and were present at the workplace on the dates agreed for data collection with their managers; eight questionnaires with incomplete and / or illegible data was excluded. 
For data collection, a Sociodemographic and Professional Characterization Questionnaire was used (which includes information on age, gender, marital status, professional category, length of professional training and current workplace, work regime and shift, considering the stressful work and has dependents to whom he cares) and the Maslach Burnout Inventory Human Services Survey (MBI-HSS), prepared by Maslach and Jackson(13), translated and validated into Portuguese $^{(14)}$ and Spanish(15). In both Brazil and Spain, the MBI-HSS consists of 22 items. In the Brazilian version, each item is distributed on a five-point scale, ranging from zero to four ("never" to "daily"), and in the Spanish version, on a seven-point scale, ranging from zero to six (" never "until" daily "). Thus, to enable the comparison of scores between countries, it was necessary to normalize them, which was performed by multiplying the scores of the Brazilian version by 600 and the Spanish version by 400 . Then, the scores of both versions of the scale went from zero to 100 .

The MBI-HSS evaluates the worker's experience in his work in three dimensions: Emotional Exhaustion (EE) (items 1, 2, 3, 6, 8, 13, 14, 16 and 20); Depersonalization (DE) (items 5, 10, 11, 15 and 22) and Professional Achievement (PA) (items 4, 7, 9, $12,17,18,19$ and 21). High values in the $\mathrm{EE}$ and DE dimensions, associated with low scores in the PA dimension, indicate burnout(14). In this study, no cutoff was adopted: the analyzes were performed by calculating the mean scores in each dimension for both Brazilian and Spanish Nursing workers.

The collected data was entered into a spreadsheet of the Microsoft Office Excel $®$ computer program, in the form of an electronic database, and later converted to the Statistical Package for the Social Sciences $\mathbb{R}$ (SPSS) 22.0 and free software R 3.3 .2 for analysis. Descriptive and analytical analyzes of the data were performed using relative frequencies, absolute, mean, standard deviation, minimum and maximum, as well as association and correlation tests between the variables. To compare the mean burnout dimensions between countries, the Student's t-test was used. In the ANOVA model, two factors were used to associate the burnout dimensions in each country with the categorical variables and the factorial ANCOVA for the association with the numerical variables, adopting a $95 \%$ confidence interval.

\section{Results}

Of the 589 study participants, $47.20 \%$ are Brazilian and $52.80 \%$ are Spanish; $89.47 \%$ are female, and $60.61 \%$ live in stable marital union (Table 1 ). The average age is 39.5 years (SD 9.36; minimum 20; maximum 64).

Table 1 - Sociodemographic and professional characterization of nursing workers. Sao Paulo, Brazil, Asturias, Spain, 2015-2016

\begin{tabular}{|c|c|c|c|}
\hline Variables & & $n^{*}=589$ & $\%^{\dagger}$ \\
\hline \multirow[t]{2}{*}{ Country } & Brazil & 278 & 47,20 \\
\hline & Spain & 311 & 52,80 \\
\hline \multirow[t]{2}{*}{ Sex } & Female & 527 & 89,47 \\
\hline & Male & 62 & 10,53 \\
\hline \multirow[t]{4}{*}{ Marital Status } & Single & 177 & 30,05 \\
\hline & Stable Union & 357 & 60,61 \\
\hline & $\begin{array}{c}\text { Divorced, separated or } \\
\text { widow }\end{array}$ & 51 & 8,66 \\
\hline & Without information & 4 & 0,68 \\
\hline \multirow[t]{2}{*}{ Professional category } & $\begin{array}{l}\text { Nursing Auxiliary/ } \\
\text { Technician }\end{array}$ & 286 & 48,56 \\
\hline & Nurse & 303 & 51,44 \\
\hline \multirow[t]{3}{*}{ Workplace } & $\begin{array}{l}\text { Pre-hospital care } \\
\qquad\left(\mathrm{SAMU}^{\ddagger}\right)\end{array}$ & 34 & 5,77 \\
\hline & Hospital care & 554 & 94,06 \\
\hline & Without information & 1 & 0,17 \\
\hline \multirow[t]{3}{*}{ Work Regime } & With stability & 148 & 25,13 \\
\hline & Without stability & 436 & 74,02 \\
\hline & Without information & 5 & 0,85 \\
\hline \multirow[t]{3}{*}{ Work shift } & Fixo & 284 & 48,22 \\
\hline & Rotativo & 279 & 47,37 \\
\hline & Sem informação & 26 & 4,41 \\
\hline \multirow{3}{*}{$\begin{array}{l}\text { Do you have people } \\
\text { depending on your } \\
\text { care? }\end{array}$} & Fixed & 183 & 31,07 \\
\hline & Rotary & 342 & 58,06 \\
\hline & Without information & 64 & 10,87 \\
\hline \multirow{3}{*}{$\begin{array}{l}\text { Do you consider your } \\
\text { job stressful? }\end{array}$} & Yes & 458 & 77,76 \\
\hline & No & 122 & 20,71 \\
\hline & Without information & 9 & 1,53 \\
\hline
\end{tabular}

${ }^{*} \mathrm{n}=$ number (absolute frequency) $;{ }^{+} \%=$ Percentage (relative frequency); ${ }^{*} \mathrm{SAMU}=$ Emergency mobile care service

Regarding professional characteristics, $48.56 \%$ are mid-level nursing workers (technical) and $51.44 \%$ are nurses; $94.06 \%$ work in hospital care, $74.02 \%$ do not have job stability, and $77.76 \%$ consider work as stressful (Table 1).

The average professional experience time is 13.5 years (SD 8.94; minimum 0.16; maximum 45) and average working time at the current workplace is 7.9 years (SD 7.05; minimum 0; maximum 40).

Regarding the dimensions of burnout, Spanish nursing workers had higher means in the DE dimension $(p=0.004)$ and Brazilian nursing workers had higher scores in the PA dimension ( $p=0.031$ ) (Table 2). 
Table 2 - Distribution and comparison of mean burnout dimensions in Brazilian and Spanish nursing workers. Sao Paulo, Brazil, Asturias, Spain, 2015-2016

\begin{tabular}{|c|c|c|c|c|c|}
\hline Dimensions & Country & $\mathbf{n}^{*}$ & $\mathbf{M}^{\dagger}$ & $\mathrm{SD}^{\ddagger}$ & $\begin{array}{c}\text { Value } \\
-p^{\S}\end{array}$ \\
\hline \multirow[t]{2}{*}{ Emotional Exaustion } & Brazil & 278 & 40 & 21 & 0,414 \\
\hline & Spain & 308 & 42 & 19 & \\
\hline \multirow[t]{2}{*}{ Depersonalization } & Brazil & 278 & 21 & 19 & 0,004 \\
\hline & Spain & 310 & 26 & 19 & \\
\hline \multirow{2}{*}{$\begin{array}{l}\text { Professional } \\
\text { Achievement }\end{array}$} & Brazil & 278 & 74 & 18 & 0,031 \\
\hline & Spain & 306 & 71 & 17 & \\
\hline
\end{tabular}

There was no evidence of association of the burnout dimensions in each country with the categorical variables gender, marital status and presence of dependents. Table 3 presents the associations with statistical significance of the burnout dimensions with the other categorical variables.

In both Spain and Brazil, nursing assistants / technicians have higher EE than nurses (main effect $p$ $=0.029$ ); hospital care workers have higher levels of
EE than prehospital care (main effect $p<0.001$ ) and participants who consider stressful work have higher levels of EE than those who do not consider stressful work (effect main $\mathrm{p}<0.001$ ). In Brazil, workers with a fixed work shift have a higher degree of EE, while in Spain they are rotating shift workers (interaction $p=0.001$ ).

The association of the DE dimension shows that in both Spain and Brazil, hospital care workers have higher levels than prehospital care (main effect $p<0.001$ ), just as workers who consider stressful work have higher ED levels than those not considering (main effect $p<0.001$ ). In Brazil, ED is higher in nurses, while in Spain it is higher in nursing assistants / technicians (interaction $p=0.024)$. In Brazil, workers with a fixed work shift have a higher degree of ED, while in Spain they are rotating shift workers (interaction $p=0.047$ ) (Table 3 ).

The data in Table 3 also shows that regarding the PR dimension, the association with job stability shows that in Spain and Brazil, workers without stability have higher PR (main effect $p=0.025$ ), as well as workers who do not consider work stressful (main effect $p=0.041$ ).

Table 3 - Association of burnout dimensions in Brazilian and Spanish nursing workers with categorical variables. Sao Paulo, Brazil, Asturias, Spain, 2015-2016

\begin{tabular}{|c|c|c|c|c|c|c|c|c|}
\hline \multirow[t]{2}{*}{ Variables } & \multicolumn{2}{|c|}{ Brazilians } & \multicolumn{2}{|c|}{ Spanish } & \multicolumn{2}{|c|}{ Total } & \multicolumn{2}{|c|}{ Value $-\mathrm{p}^{*}$} \\
\hline & $\mathrm{n}^{\dagger}$ & $\mathrm{M}^{\ddagger}\left(\mathrm{SD}^{\S}\right)$ & $\mathrm{n}^{\dagger}$ & $\mathrm{M}^{\ddagger}\left(\mathrm{SD}^{\S}\right)$ & $\mathrm{n}^{\dagger}$ & $\mathrm{M}^{\ddagger}\left(\mathrm{SD}^{\S}\right)$ & Interation & ME॥ \\
\hline \multicolumn{9}{|c|}{ Emotional Exhaustion } \\
\hline \multicolumn{9}{|c|}{ Professional category } \\
\hline NA/NT" & 168 & $40(22)$ & 75 & $47(18)$ & 243 & $43(21)$ & & \\
\hline Nurse & 65 & $39(18)$ & 229 & $40(19)$ & 294 & $40(19)$ & 0,112 & 0,029 \\
\hline Total & 233 & $40(21)$ & 304 & $42(19)$ & 537 & $41(20)$ & & \\
\hline \multicolumn{9}{|l|}{ Workplace } \\
\hline $\mathrm{PHC}^{* *}$ & 10 & $25(11)$ & 22 & $21(20)$ & 32 & $22(18)$ & & \\
\hline $\mathrm{HC}^{\dagger+}$ & 222 & $41(21)$ & 282 & $43(18)$ & 504 & $42(20)$ & 0,382 & $<0,001$ \\
\hline Total & 232 & $40(21)$ & 304 & $42(19)$ & 536 & $41(20)$ & & \\
\hline \multicolumn{9}{|l|}{ Work shift } \\
\hline Fixed & 204 & $40(21)$ & 41 & $30(26)$ & 245 & $39(22)$ & & \\
\hline Rotary & 11 & $29(10)$ & 260 & $43(18)$ & 271 & $43(17)$ & 0,001 & 0,807 \\
\hline Total & 215 & $40(21)$ & 301 & 42(19) & 516 & $41(20)$ & & \\
\hline \multicolumn{9}{|c|}{ Considers work stressful } \\
\hline Yes & 180 & $45(20)$ & 246 & $45(18)$ & 426 & $45(19)$ & & \\
\hline No & 49 & $24(16)$ & 55 & $25(15)$ & 104 & $25(15)$ & 0,939 & $>0,001$ \\
\hline Total & 229 & $40(21)$ & 301 & $42(19)$ & 530 & $41(20)$ & & \\
\hline \multicolumn{9}{|c|}{ Depersonalization } \\
\hline \multicolumn{9}{|c|}{ Professional category } \\
\hline $\mathrm{NA} / \mathrm{NT} \pi$ & 168 & 21(19) & 75 & 29(19) & 243 & 23(19) & 0,024 & 0,960 \\
\hline Nurse & 65 & $25(18)$ & 229 & $25(19)$ & 294 & $25(19)$ & & \\
\hline Total & 233 & $22(19)$ & 304 & $26(19)$ & 537 & $24(19)$ & & \\
\hline \multicolumn{9}{|l|}{ Workplace } \\
\hline $\mathrm{PHC}^{* *}$ & 10 & 12(11) & 22 & $10(12)$ & 32 & 10(12) & 0,398 & $>0,001$ \\
\hline $\mathrm{HC}^{\dagger+}$ & 222 & $23(19)$ & 282 & $27(19)$ & 504 & $25(19)$ & & \\
\hline Total & 232 & $22(19)$ & 304 & $26(19)$ & 536 & $24(19)$ & & \\
\hline \multicolumn{9}{|l|}{ Work shift } \\
\hline Fixed & 204 & $22(18)$ & 41 & $17(21)$ & 245 & 21(19) & 0,047 & 0,380 \\
\hline Rotary & 11 & 18(14) & 260 & $27(18)$ & 271 & $27(18)$ & & \\
\hline Total & 215 & 22(18) & 301 & $26(19)$ & 516 & $24(19)$ & & \\
\hline
\end{tabular}


Table 3 - (continuation)

\begin{tabular}{|c|c|c|c|c|c|c|c|c|}
\hline \multirow[t]{2}{*}{ Variables } & \multicolumn{2}{|c|}{ Brazilians } & \multicolumn{2}{|c|}{ Spanish } & \multicolumn{2}{|c|}{ Total } & \multicolumn{2}{|c|}{ Value - $\mathbf{p}^{*}$} \\
\hline & $\mathrm{n}^{\dagger}$ & $\mathrm{M}^{\ddagger}\left(\mathrm{SD}^{\S}\right)$ & $\mathrm{n}^{\dagger}$ & $\mathrm{M}^{\ddagger}\left(\mathrm{SD}^{\S}\right)$ & $\mathrm{n}^{\dagger}$ & $\mathrm{M}^{\ddagger}\left(\mathrm{SD}^{\S}\right)$ & Interation & ME" \\
\hline \multicolumn{9}{|c|}{ Considers work stressful } \\
\hline Yes & 180 & $25(19)$ & 246 & $28(19)$ & 426 & $27(19)$ & 0,977 & $<0,001$ \\
\hline No & 49 & $14(14)$ & 55 & $17(15)$ & 104 & $16(14)$ & & \\
\hline Total & 229 & $22(19)$ & 301 & $26(19)$ & 530 & $24(19)$ & & \\
\hline \multicolumn{9}{|c|}{ Professional Achievement } \\
\hline \multicolumn{9}{|l|}{ Work Regime } \\
\hline With stability & 17 & $63(19)$ & 126 & $73(19)$ & 143 & $72(19)$ & 0,309 & 0,025 \\
\hline Without stability & 214 & $71(18)$ & 176 & $76(16)$ & 390 & $73(17)$ & & \\
\hline Total & 231 & $71(18)$ & 302 & $74(17)$ & 533 & $73(17)$ & & \\
\hline \multicolumn{9}{|c|}{ Considers work stressful } \\
\hline Yes & 180 & $70(17)$ & 246 & $73(18)$ & 426 & $72(17)$ & 0,272 & 0,041 \\
\hline No & 49 & $72(21)$ & 55 & $79(14)$ & 104 & $76(18)$ & & \\
\hline Total & 229 & $71(18)$ & 301 & $74(17)$ & 530 & $73(17)$ & & \\
\hline
\end{tabular}

Figure 1 shows the association of burnout dimensions with numerical variables. No relationship was found between age and EE dimension (Regression Coefficient $(C R)=0.261 ; p$-value interaction $=0.209 ; 95 \%$ Confidence Interval (CI): -0.14 to 0.66 ; Coefficient of Determination $\left.\left(R^{2}\right)=0.009\right)$. In Brazil, there is a positive correlation between the length of professional experience and $E E$, ie, as the length of professional experience increases, so does the level of EE (CR $=0.652$; p-value interaction $=0.005 ; 95 \% \mathrm{CI}: 0.19)$. a $\left.1.10 ; \mathrm{R}^{2}=0.023\right)$, whereas in Spain this interaction is not significant.
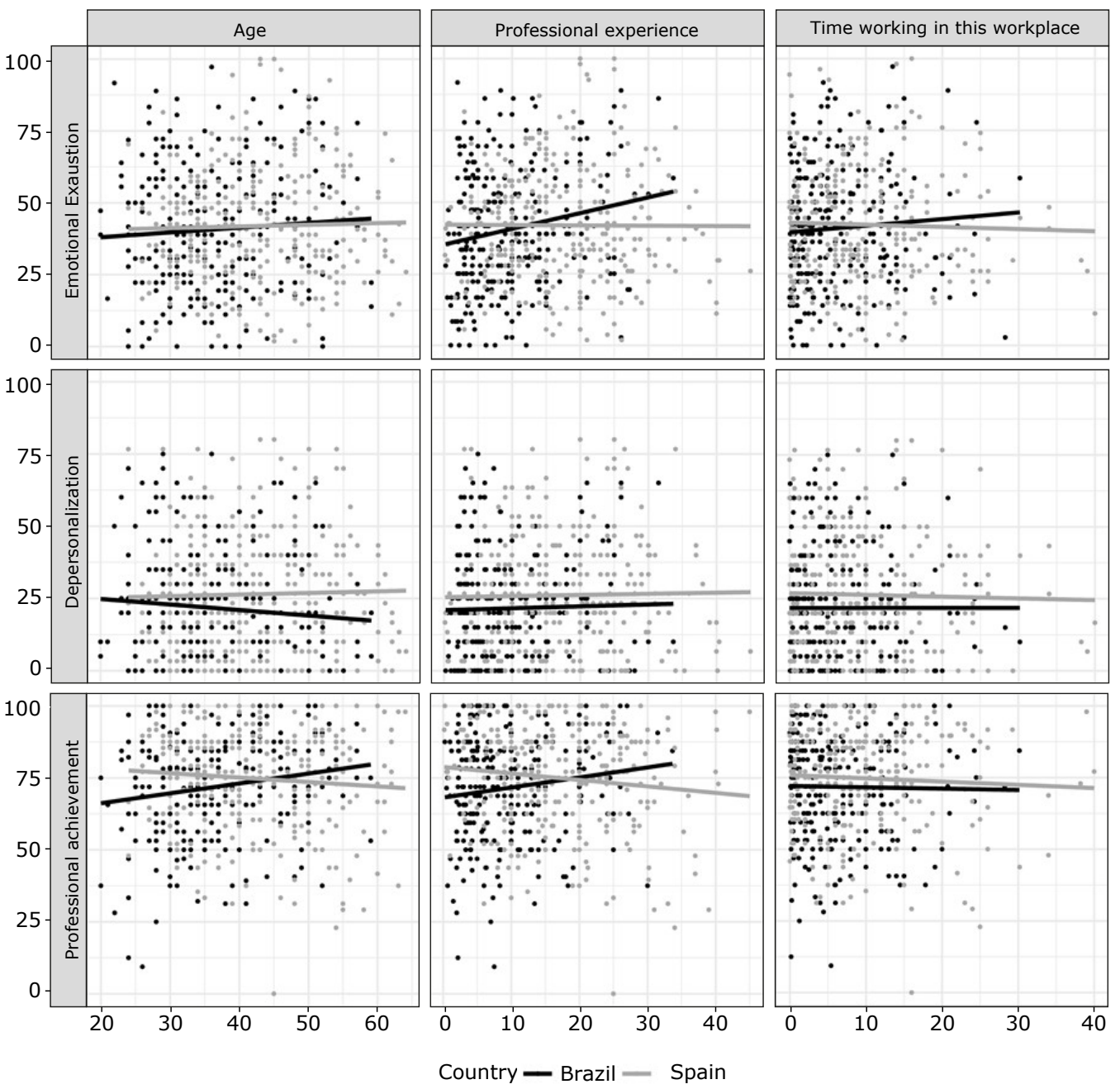

Figure 1 - Relationship of the dimensions of burnout with the variables age, professional experience and length of work in the current workplace. Sao Paulo, Brazil, Asturias, Spain, 2015-2016 
In addition, the data indicate that in Brazil the longer the working time in the workplace, the higher the $\mathrm{EE}$, while in Spain, the longer the working time in the workplace, the lower the $\mathrm{EE}(\mathrm{CR}=0.552 ; \mathrm{p}$-value interaction $=0.050$; 95\% CI: -0.001 to $1.106 ; \mathrm{R}^{2}=0.010$ ).

No relationship was found between the numerical variables age $(C R=-0.086 ; p$-value interaction $=0.661$; 95\% CI: -0.47 to $\left.0.29 ; R^{2}=0.010\right)$, work experience $(C R=0.148 ; p$-value interaction $=0.503 ; 95 \% C I:-0.28$ to $0.58 ; R^{2}=0.012$ ) and working time in the workplace $(\mathrm{CR}=0.237 ; \mathrm{p}$-value interaction $=0.372 ; 95 \% \mathrm{CI}:-0.28$ to 0.75$) ; R^{2}=0.010$ ) with the dimension $D E$.

When associating the PA dimension with the numerical variables, a positive correlation was observed between age and PA in the Brazilian workers, and a negative correlation in the Spanish workers $(C R=0.475$; p-value interaction $=0.008 ; 95 \% \mathrm{CI}: 0.12$ to 0.82 ). ( 2 = 0.023); In Brazil there is a positive correlation between professional experience and PA, while in Spain this correlation is negative $(C R=0.515 ; p$-interaction value $=0.012 ; 95 \% \mathrm{CI}: 0.11$ to $\left.0.91 ; \mathrm{R}^{2}=0.024\right)$. There was no correlation between working time in the workplace and $\mathrm{PA}(\mathrm{CR}=0.025 ; \mathrm{p}$-interaction value $=0.920$; 95\% CI: -0.46 to $\left.0.51 ; R^{2}=0.012\right)$.

\section{Discussion}

Currently, few studies analyze burnout syndrome in nursing workers from a multicultural perspective. The sample of this study consisted of Brazilian and Spanish young adult workers, with female predominance, corroborating the results obtained in other studies (16-19). This study also demonstrates that the technical division of labor, the lack of job stability and the perception that work is stressful are factors that permeate the Brazilian and Spanish scenario.

There was a great variation in the international literature when comparing, in Nursing workers, the averages of each dimension of burnout, even within the countries studied here ${ }^{(2,17,20-21)}$. In this study, when analyzing the mean burnout dimensions in Brazilian and Spanish nursing workers, it is observed that, despite low DE and high PR levels, there are average EE levels, indicating an important preventive factor to be worked on, since EE is considered the first stage of burnout, leading to ED and may interfere with PR. The literature shows that EE is a result of work overload and conflicts in interpersonal relationships and is related to the lack of energy to perform work activities, the feeling of being overloaded, fatigued and with physical and mental exhaustion. ED is a form of coping with $E E$, an attempt to distance oneself from the recipients of one's work due to $E E$, which leads the worker to a negative response in the interpersonal context, treating the recipients of his work with cynicism or coldness as if were objects, such as those responsible for their problems, and the reduced PA results from the self-assessment process, when the worker feels incompetent, failed, low self-esteem and poor work performance ${ }^{(4)}$.

In addition, EE is associated with job dissatisfaction, intention to quit next year and feeling overworked(17).

Increasingly, when it comes to the organization of work, the influence of the leader in maintaining a work and team climate conducive to the achievement of workers and the achievement of organizational goals is becoming increasingly evident. In this context, the continuous formation of leaders and the team's maturity may represent a key point for the construction of strategies to promote quality of life at work and, consequently, reduction of burnout.

The comparison of the burnout dimensions between countries showed significant differences, where Brazilian nursing workers had higher PA, while Spanish nursing workers had higher DE.

Another observed difference has to do with work organization so that EE and DE are higher in Brazilian Nursing workers with a fixed work shift, whereas in Spain this occurs in the rotating shift.

The professional category also seems to play an important role in the different dimensions of burnout by country. This study observed that EE levels were higher in Nursing assistants / technicians than in nurses, both in Brazil and Spain. It is important to highlight the technical and social division of Nursing work, which not only exposes workers to different types of workloads but also to different sickening processes, since higher-level workers are dedicated to the activities of greater intellectual and social demands management and mid-level workers to manual activities that require more physical effort.

In the Brazilian and Spanish contexts, the duties of Nursing assistants / technicians include direct patient care activities, such as cleaning and hygiene techniques, causing greater physical wear to the category. On the other hand, direct pressure during strict supervision and quality of care, both by users and by the supervisor (nurse), is also an element capable of increasing EE in these workers.

This data differs from research conducted with Italian hospital health workers (22), but corroborates a Brazilian study that showed high levels of EE associated with low educational level(23).

Regarding the higher levels of DE in Brazilian nurses than in Nursing assistants / technicians, the data coincide with the results of a survey (22) conducted in Italy and a study ${ }^{(23)}$ of Brazilian hospital health workers that found an association of DE. with higher educational level in 
nurses. It is assumed that the higher level of education is linked to the attribution of higher responsibilities and higher expectations of these workers in relation to the profession. However, another study was consistent with results in the Spanish population, which showed higher levels of DE in nursing technicians / assistants ${ }^{(24)}$.

In both Spain and Brazil, the results indicated higher levels of EE and DE in hospital care nursing workers. It seems possible that these results are due to the peculiarities of the work environment: while the pre-hospital is characterized by greater dynamism and freedom in the decisions themselves, in the hospital, the work is done in closed units, with patients hospitalized for long periods of time in continuous and direct contact with supervisors and managers, and more frequently performing administrative tasks.

Considering stressful work showed an association with burnout, since these nursing workers had higher levels of $\mathrm{EE}$ and $\mathrm{DE}$, and lower $\mathrm{PR}$, corroborating the literature, which indicates stress as a predictor of burnout ${ }^{(22,25)}$. Other authors found an association between stress and two of the burnout dimensions: $\mathrm{EE}$ and $\mathrm{DE}^{(26-28)}$.

The data also showed that Brazilian and Spanish workers without stability have higher levels of PR. While on the one hand, instability may be linked to the uncertainty of not having a stable job, on the other, job stability may imply lower expectations for professional growth. The association and comparison of EE with job stability in this study were not significant, contrasting a study with hospital health workers in Brazil, where higher EE scores were found in workers with stability than in those without stability ${ }^{(29)}$.

Moreover, the results showed that, contrary to what happens in Brazil, Spain, younger nursing workers with shorter professional experience have lower PR. These results are similar to those previously found in the occupational environment ${ }^{(22,30)}$. Thus, another Brazilian study with hospital health workers also found an association between older age and higher $\mathrm{PR}^{(29)}$.

In Brazil, as the length of professional experience increases, so do the levels of EE, while in Spain this correlation is nil. The influence of working time in the same workplace also points to contradictory data: while in Spain, working in the same workplace for a longer time is associated with lower EE, in Brazil, the opposite occurs, collaborating with the study conducted in Italy ${ }^{(22) .}$ This may be due to Spanish Nursing workers developing a more effective work adaptation process and not accumulating time responsibilities in the same workplace.

Considering the data related to both contexts, the need to implement intervention measures to reduce the risks of burnout development is evident. In this regard, the studies reinforce greater effectiveness and durability of interventions that address both the individual and organizational levels. The individual approach includes psychoeducational actions, with discussion of risk factors, relaxation practices, development of coping strategies, among others ${ }^{(31-32)}$. At the organizational level, interventions interfere with working conditions, as can be seen in the study with Australian nurses, which evaluated the impact of an organizational intervention in reducing occupational stress, using a tool to assess workloads, increasing staff numbers, access to professional development, among others, and achieved a significant reduction in psychological distress and emotional exhaustion and a significant improvement in job satisfaction ${ }^{(33)}$.

It is worth highlighting teamwork as a health strengthening for nursing workers, given that it can provide a collaborative practice in which roles are well defined and there is a focus to be achieved, although there is the specificity of each action. From this perspective, it is essential to involve the subjects in the process of construction and redesign of the work with a view to improving the work climate, team climate and, consequently, valuing professionals.

The limitations of this study are related to its design, which makes the cause and effect relationship impossible, the number of participants and the lack of some variables that may interfere with burnout levels, such as resilience ${ }^{(34-35)}$, which can lead the subject to act positively in the face of adversity, becoming a protective factor in the development of this problem. It may be interesting that the study also includes other health workers, including those in primary care, considering the various scenarios of action and their relevance to health at the international level. However, the data show similarities in the contexts and support the planning of actions at the individual and collective levels in the face of illness at work and the need to maintain patient quality and safety.

\section{Conclusion}

In conclusion, despite cultural, economic and social differences, Nursing workers face similar problems, with some particularities. Brazilian and Spanish nursing workers have moderate levels of EE, low DE levels and high PA. When comparing the populations, it was observed that the Brazilians had higher PA averages and the Spanish higher DE averages. It was also verified that dimensions of burnout are associated with some sociodemographic and work characteristics, such as: age; professional category; workplace; work regime; work shift; time of professional experience; working time in the same workplace and consider stressful work.

The investigation of burnout in nursing workers and its associated factors, as well as prevention and coping 
mechanisms, becomes indispensable as an instrument of evaluation and support for the implementation of preventive and interventional measures, seeking to protect the health of the worker and, consequently, patient safety and organizational success.

\section{References}

1. Dewa CS, Loong D, Bonato S, Thanh NX, Jacobs P. How does burnout affect physician productivity? A systematic literature review. BMC Health Serv Res. 2014; 14:325. doi: https://doi.org/10.1186/1472-6963-14-325

2. Portero S, Vaquero M. Professional burnout, stress and job satisfaction of nursing staff at a university hospital. Rev. Latino-Am. Enfermagem. 2015; 23(3):543-52. doi: http://dx.doi.org/10.1590/0104-1169.0284.2586

3. Perry L, Lamont S, Brunero S, Gallagher R, Duffield C. The mental health of nurses in acute teaching hospital settings: a cross-sectional survey. BMC Nurs. [internet]. 2015 [cited Dec 29, 2017]; 14:15. Available from: https://bmcnurs.biomedcentral.com/track/pdf/10.1186/ s12912-015-0068-8

4. Maslach C, Schaufeli WB, Leiter MP. Job Burnout. Annual Rev Psychol. 2001;52: 397-422. doi: https:// doi.org/10.1146/annurev.psych.52.1.397

5. Baptista PCP, Pustiglione M, Almeida MCS, Felli VEA, Garzin ACA, Melleiro MM. Nursing workers health and patient safety: the look of nurse managers. Rev Esc Enferm USP. [Internet] 2015 [cited Dec 29, 2017]; 49(Esp2):1206. Available from: http://www.scielo.br/pdf/reeusp/ v49nspe2/en_1980-220X-reeusp-49-spe2-0122.pdf

6. Silveira ALP, Colleta TCD, Ono HRB, Woitas LR, Soares $\mathrm{SH}$, Andrade VLA, et al. Burnout Syndrome: consequences and implications of an increasingly prevalent reality in health professionals' lives. Rev Bras Med Trab. [internet].2016[cited 3 Marc 2019];14(3):275-84. Available from: http://www.rbmt.org.br/details/121/pt$\mathrm{BR} /$ sindrome-de-burnout--consequencias-e-implicacoesde-uma-realidade-cada-vez-mais-prevalente-na-vidados-profissionais-de-saude

7. Admi $H$, Yael EM. Do hospital shift charge nurses from different cultures experience similar stress? An international cross sectional study. Int J Nurs Stud. 2016; 63: 48-57. doi: https://doi.org/10.1016/j.ijnurstu.2016.08.005

8. Granero A, Blanch JM, Ochoa P. Labor conditions and the meanings of nursing work in Barcelona. Rev. LatinoAm. Enfermagem. 2018;26:e2947. doi: http://dx.doi. org/10.1590/1518-8345.2342.2947

9. Blanca-Gutiérrez JJ, Arias-Herrera A. Burnout syndrome among nursing staff: hospital-environment stress associations, Andalucia, Spain. Enferm Univ. [internet]. 2018 Mar [cited 2019 Mar 6]; 15(1): 30-44. Available: http://www.scielo.org.mx/scielo.php?script=sci_
arttext\&pid=S1665-70632018000100030\&lng=es. http:// dx.doi.org/10.22201/eneo.23958421e.2018.1.62903.

10. Cañadas-De la Fuente GA, Albendín-García $L$, de la Fuente EI, San Luis C, Gómez-Urquiza JL, Cañadas GR. Burnout in Nursing Professionals Performing Overtime Workdays in Emergency and Critical Care Departments. Spain. Rev Esp Salud Publica. [internet]. 2016 set [cited Marc 2, 2019]; 90: e1-9. Available from: http://www. mscbs.gob.es/biblioPublic/publicaciones/recursos_ propios/resp/revista_cdrom/VOL90/ORIGINALES/ RS90C_GCF.pdf

11. Soto-Rodríguez A, Pérez-Fernandez MR. Burnout syndrome and stress of nursing staff in a Ourense hospital. Rev ROL Enferm. [internet]. 2015 fev [cited Feb 28, 2018];38(2):101-6. Available from: http:// www.e-rol.es/articulospub/articulospub_paso3.php?arti culospubrevista $=38(02)$ \&itemrevista $=101-106 \#$

12. Machado $M H$, Oliveira E, Lemos W, Lacerda WF, Aguiar W Filho, Wermelinger $M$, et al. Mercado de trabalho da enfermagem: aspectos gerais. Enferm Foco. [internet]. 2015[cited Mar 2, 2019]; 6 (1/4): 43-78. Available from: http://revista.cofen.gov.br/index.php/ enfermagem/article/view/691/301

13. Maslach C, Jackson SE. MBI- Inventário "Burnout" de Maslach. Madrid: TEA Ediciones; 1997.

14. 14. Lautert L. O desgaste do Profissional enfermeiro. Tese. Salamanca: Universidad Pontificia Salamanca; 1995 [acesso mar 9 2017]. Disponível em:http://hdl. handle.net/10183/11028

15. Seisdedos N. MBI- Inventario Burnout de Maslach: manual. Madrid: TEA; 1997.

16. Panunto MR, Guirardello EB. Professional nursing practice: environment and emotional exhaustion among intensive care nurses. Rev. Latino-Am. Enfermagem. 2013; 21(3):765-72. doi: http://dx.doi.org/10.1590/ S0104-11692013000300016

17. Gasparino RC. Burnout syndrome in the nursing team of a teaching hospital. Cogitare Enferm. 2014 apr/jun [cited Dec 28, 2017]; 19(2):232-8. Available from: https:// revistas.ufpr.br/cogitare/article/view/32649/22725

18. Geuens N, Van Bogaert P, Franck E. Vulnerability to burnout within the nursing workforce: The role of personality and interpersonal behaviour. J Clin Nurs. 2017;26(23-24):4622-33. doi: http://dx.doi. org/10.1111/jocn. 13808

19. Aiken LH, Sloane DM, Bruyneel L, Heede KV, Sermeus W. Nurses' reports of working conditions and hospital quality of care in 12 countries in Europe. Int J Nurs Stud. 2013; 50(2):143-53. doi: http://dx.doi. org/10.1016/j.ijnurstu.2012.11.009

20. Guo J, Chen J, Fu J, Ge X, Chen M, Liu Y. Structural empowerment, job stress and burnout of nurses in 
China. Appl Nurs Res. 2016; 31: 41-5. doi: https://doi. org/10.1016/j.apnr.2015.12.007

21. Zhang L, You L, Liu K, Zheng J, Fang J, Lu M, et al. The association of Chinese hospital work environment with nurse burnout, job satisfaction, and intention to leave. Nurs Outlook.[Internet]. 2014[cited dec 29, 2017]; 62(2):128- 37. Available from: https://www.ncbi.nlm.nih. gov/pmc/articles/PMC3959248/pdf/nihms540287.pdf

22. Mattei A, Fiasca F, Mazzei M, Necozione S, Bianchini V. Stress and Burnout in Health-Care Workers after the 2009 L'Aquila Earthquake: A Cross-Sectional Observational Study. Front Psychiatry. 2017; 8: 98. doi: http://doi.org/10.3389/fpsyt.2017.00098

23. Paiva LC, Canário ACG, China ELCP, Gonçalves AK. Burnout syndrome in health-care professionals in a university hospital. Clinics. (São Paulo). 2017; 72(5): 305-9. doi: http://doi.org/10.6061/clinics/2017(05)08

24. Arrogante $O$. Mediator effect of resilience between burnout and health in nursing staff. Enferm Clín. 2014; 24(5): 283-9. doi: https://doi.org/10.1016/j. enfcli.2014.06.003

25. Adriaenssens J, De Gucht V, Maes S. Determinants and prevalence of burnout in emergency nursing: a systematic review of 25 years of research. Int J Nurs Stud. 2015; 52(2): 649-61. doi: https://doi. org/10.1016/j.ijnurstu.2014.11.004

26. Ríos-Risquez MI, García-Izquierdo M. Patient satisfaction, stress and burnout in nursing personnel in emergency departments: A cross-sectional study. Int J Nurs Stud. 2016; 59:60-67. doi: https://doi. org/10.1016/j.ijnurstu.2016.02.008

27. Li B, Bruyneel L, Sermeus W, Van den Heede K, Matawie K, Aiken L, et al. Group-level impact of work environment dimensions on burnout experiences among nurses: a multivariate multilevel probit model. Int J Nurs Stud. 2013; 50: 281-91. doi: https://doi.org/10.1016/j. ijnurstu.2012.07.001

28. Khamisa N, Peltzer K, Oldenburg B. Burnout in relation to specific contributing factors and health outcomes among nurses: a systematic review. Int J Environ Res Public Health. 2013; 10(6): 2214-40. doi: https://doi.org/10.3390/ijerph10062214

29. Ebling M, Carlotto MS. Burnout syndrome and associated factors among health professionals of a public hospital. Trends Psychiatry Psychother. 2012;34(2): 93-100. doi: http://dx.doi.org/10.1590/ S2237-60892012000200008
30. Gracia-Gracia P, Oliván-Bláquez B. Burnout and Mindfulness Self-Compassion in Nurses of Intensive Care Units. Holist Nurs Pract. 2017; 31(4):225-33. doi: http://doi.org/10.1097/HNP.0000000000000215

31. Nowrouzi B, Lightfoot $N$, Larivière $M$, Carter L, Rukholm E, Schinke $R$, et al. Occupational Stress Management and Burnout Interventions in Nursing and Their Implications for Healthy Work Environments: A Literature Review. Workplace Health Saf. 2015; 63 (7): 308-15.doi: https://doi. org/10.1177/2165079915576931

32. Westermann C, Kozak A, Harling M, Nienhaus A. Burnout intervention studies for inpatient elderly care nursing staff: Systematic literature review. Int J Nurs Stud. 2014; 51:63-71. doi: https://doi.org/10.1016/j. ijnurstu.2012.12.001

33. Rickard G, Lenthall S, Dollard M, Opie T, Knight $S$, Dunn $S$, et al. Organisational intervention to reduce occupational stress and turnover in hospital nurses in the Northern Territory, Australia. Collegian. [internet]. 2012 [cited Mar 2, 2019]; 19(4): 211-21. Available from: https://www.ncbi.nlm.nih.gov/pubmed/23362607

34. Bamonti P, Conti E, Cavanagh C, Gerolimatos L, Gregg J, Goulet C, et al. Coping, Cognitive Emotion Regulation, and Burnout in Long-Term Care Nursing Staff: A Preliminary Study. J Appl Gerontol. 2017;1:733464817716970. doi: http://doi. org/10.1177/0733464817716970

35. Guo YF, Luo YH, Lam L, Cross W, Plummer V, Zhang JP. Burnout and its association with resilience in nurses: a cross-sectional study. J Clin Nurs. 2018;27(1-2):441-9. doi: http://doi.org/10.1111/jocn.13952

Received: Nov $27^{\text {th }} 2018$ Accepted: Jun $14^{\text {th }} 2019$
Corresponding author:

Patricia Campos Pavan Baptista

E-mail: pavanpati@usp.br

(iD) https://orcid.org/0000-0003-1433-6456
Copyright $\odot 2019$ Revista Latino-Americana de Enfermagem This is an Open Access article distributed under the terms of the Creative Commons (CC BY).

This license lets others distribute, remix, tweak, and build upon your work, even commercially, as long as they credit you for the original creation. This is the most accommodating of licenses offered. Recommended for maximum dissemination and use of licensed materials. 